\title{
The World According to Boaz: Wealth, Power, and Justice in the Book of Ruth* Viktor Ber
}

In the story of the book of Ruth as well as in its characters social and legal, political and theological motifs are interconnected. In this paper I intend to analyze the function of those motifs in the narrative strategy of the narrator and to outline the further possible considerations of wealth, power and justice in community which this biblical book opens. In this I will focus on Boaz - an influential man - and the part he plays in the Ruth' narrative.

\section{Strategy of reading the book of Ruth}

Two different traditions place the book of Ruth in two different literary and canonical contexts. According to ancient Greek codices and the order of the traditional Christian canon derived from them, Ruth is found among the "historical" books; it thus precedes "the books of Kings", as the Greek tradition of the Septuagint calls already the books of Samuel. The traditional Jewish ordering places the book of Ruth in the third part of the canon, the so-called Writings. ${ }^{2}$ This double literary-canonical context suggests the possibility of at least two strategies of reading $R$ uth, which need not be mutually exclusive.

Placing the book of Ruth after the book of Judges and before the books of Samuel and Kings highlights the Davidic line, underlines the dimension of Ruth as a prehistory of King David and the Davidic monarchy of sorts. The book of Ruth in fact culminates in the "revealing" of the significance of the characters and events of this apparently purely family story for wider "political history" of Israel and Judah. ${ }^{3}$

In the reception of the book Ruth in the Jewish tradition liturgical considerations have played a part - within the section of Writings Ruth belongs among the so-called Megillot, or Festival Scrolls - more specifically the five scrolls associated with various festivals of the Jewish year, in the course of which they were used liturgically. ${ }^{4}$ Besides the Davidic and liturgical focus, one is justified to look for wisdom aspects in the book. ${ }^{5}$ On this view it would not be

1 The word "Ruth" in italics refers to the biblical book of Ruth. The word "Ruth" without italics refers to a character of this biblical book Ruth. In expressions such as "the book of Ruth" there are no italics.

2 The order of the individual books within the section Writings took long to settle. In the standard critical edition of the Hebrew Bible (Biblia Hebraica Stuttgartensia) the book of Ruth is placed after the books of Psalms, Proverbs, and Job, as the first of the five so-called Festival Scrolls (see below for more on this term), although in the original Leningrad Codex (L) the books of Chronicles are also placed at the beginning of Writings; cf. Karl ELLIGER - Wilhelm RUDOLPH - H. P. RÜGER (ed.), Biblia Hebraica Stuttgartensia, Stuttgart: Deutsche Bibelgesellschaft, 1990, p. xi. According to the order of the Babylon Talmud (Baba Bathra 14b) Ruth is even found at the very beginning of the section of Writings; cf. Rolf RENDTORFF, The Old Testament: An Introduction, Philadelphia, Pennsylvania: Fortress Press, 1986, p. $245 \mathrm{f}$.

3 Of course it is not just a question of order in the canon - already the opening words of Ruth place the book in the context of the "time of judges". The concluding genealogy of Perez linking Boaz and Obed with David sets Ruth in Davidic context. Based on structural links Harold Fisch sets Ruth in the extensive "covenant history" leading up to King David. Part of this structure is also the narrative of Lot (esp. concerning Lot, the destruction of Sodom and Lot's daughters in Gen 19) and of Judah and Tamar (Gen 38); Harold FISCH, Ruth and the Structure of Covenant History, Vetus Testamentum, vol. 32, 4/1982.

4 Rolf RENDTORFF, The Old Testament, p. 258. Ruth is read at the Festival of Weeks (Shavu'ot).

5 Ibid., p. 260f. On the wisdom features of the Writings and especially the book of Ruth cf. also Robert GORDIS, Religion, Wisdom and History in the Book of Esther: A New Solution to an Ancient Crux, Journal of Biblical Literature, vol. 100, 3/1981, pp. 365, 374. James L. CRENSHAW, Method in Determining Wisdom Influence upon “Historical” Literature, Journal of Biblical Literature, vol. 88, 2/1969, exhorts to caution in looking for wisdom motifs in biblical literature. 
merely a such and such presentation (or an apology) of David's ancestors, but also a narrative elaboration and reflection of consequential topics, such as the integration of a female foreigner into the community, the community's social stability (survival of the poor, the role of the rich and influential) - in short, numerous questions of the community's practical functioning. Last but not least, it is a theological narrative reflection, though a fairly indirect and subtle one.

\section{Wealth, power, and justice in the narrative of Ruth: focused on Boaz}

Economic and social motifs are undeniably present in the narrative, often expressly formulated, whether by the narrator or by the characters - the plot is based on the contrast of the situation of famine in Bethlehem of Judea in the introduction to the narrative and the subsequent situation of harvest in an obviously prosperous Bethlehem, where Naomi returns from Moab poor, without means, feeling socially excluded. ${ }^{6}$ She is accompanied by a foreigner - the Moabite Ruth, which is another potential source of tension and conflict. ${ }^{7}$ The reader asks, of course, how the women will deal with the situation and how they will be received by the Bethlehem community (represented at first by the voices of women in Ruth 1:19). In the background there is the question of the broader meaning of this narrative. The character crucial for the two women in the course of further narrative is Boaz - a rich and influential man.

\section{Boaz as a man of affluence}

From the very first time Boaz appears, he is characterized as an influential, rich, and apparently successful man. The very name Boaz (probably "power in him") signifies the character's role in the community: he is the "pillar of community", "the community's buttress". The narrator directly characterizes him as 'ish gibbor hayil (Ruth 2:1). ${ }^{9}$ The word gibbor means powerful, strong, the word hayil can also be translated as "capable"; however, in some cases there is a nuance of meaning referring to moral integrity (Ex 18:21.25) - thus also further in the book of Ruth of Ruth herself (Ruth 3:11). ${ }^{10}$

The narrator indirectly narratively characterizes Boaz as a man of affluence by means of the events of the narrated story: he is the one who comes to the field even though his supervisors are present there, he makes the impression of a responsible man, he takes interest in what happens in his field and among his people; people notice his arrival and exchange greetings with him (Ruth 2:4). Boaz issues orders several time, the narrative clearly implies that they are strictly observed (the supervisor gives information concerning Ruth, Ruth obediently answers and stays in the field - though certainly in her own interest, the servants do not reproach or rebuke Ruth, in fact they even drop ears of corn for her to glean); Boaz is capable of immediately organizing a meeting of town elders (4:2); by handling the delicate situation at the gate Boaz proves that he is not considered "an influential man" ('ish gibbor hayil) by accident.

6 Later on, a "parcel of land" belonging to Naomi appears in the narrative (Ruth 4:3), Naomi is also aware that she has at least one relative in Bethlehem, Boaz (2:20). Nonetheless, Naomi's bitterness in Ruth 1:19-21 is fairly authentic and credible. Naomi need not be certain of the validity of her claim to the land; much less can she estimate how helpful the relatives of her deceased husband will be.

7 Apart from ethnically motivated distrust of Ruth Naomi can also feel distrust of her daughters in law, including Ruth, with respect to the death of her two sons - Fewell and Gun point out the parallel with the story of Judah and Tamar in Gen 38; Danna Nolan FEWELL - David Miller GUNN, Compromising Redemption: Relating Characters in the Book of Ruth, Louisville, Kentucky: Westminster/John Knox, 1990, p. 72ff.

8 Danna Nolan FEWELL - David Miller GUNN, Compromising Redemption, p. 40, note 28 (see p. 115).

9 , English Standard Version translates "a worthy man", New International Version “a man of standing", King James Version "a mighty man of wealth".

10 Cf. also 1 Kings 1:42.52 (in v. 52 the term is the opposite of the term ra'ah (רָָָָ) - "evil". In the sense of "rich" at Gen 34:29; Num 31:9; Deut 8:17 and others); in other contexts the term refers to the sphere of combat: "military power", "bravery" etc. 
The narrator also characterizes Boaz by means of religious and ethical values: he is the one who greets in the name of the Lord and receives the Lord's blessing through his servants (Ruth 2:4) - he is therefore a true "man of the Lord" (that is why his son will be called Obed, i.e., "Servant [of the Lord]"); in his dealing with Ruth (especially at night at the threshing floor) positive perception of Boaz from the point of view of the values of the implied reader clearly prevails - Boaz is informed of the situation of Naomi and Ruth (Ruth 2:11) and appreciates Ruth's loyalty; he acts in accordance with the precepts of the Torah, i.e., he leaves enough for the poor in the field (Lev 19:9f; 23:22; Deut 24:19-22), he does not take the potential wife of another man (the formal claim of the other redeemer is greater and Boaz knows that it is).

In short, Boaz is an important man in his community, he is beneficial to it - he provides work and subsistence, he contributes to the community's stability.

\section{The reverse side of affluence and status}

Boaz's role of a rich and influential "pillar of community" has a purpose in the narrative. The reader is led to perceive him from the perspective of the two main female characters, Naomi and Ruth. From their point of view Boaz is associated with expectations; when these are not fulfilled, he becomes - at Naomi's incentive - the object of Ruth's assertive action, if not outright seduction or attempt at manipulation.

\section{Boaz associated with expectations}

Boaz is first of all presented as Naomi's relative (or acquaintance ${ }^{11}$ ), an influential man of the clan of her deceased husband Elimelech. The narrator therefore from the very beginning places Boaz in the context of Naomi's and Ruth's life. Commentators have frequently taken notice of the "chance"12 related in Ruth 2:3 (Ruth chances to come to the field of a relative). This chance points to expectations which according to the narrator transcend the plans and ideas of Naomi and Ruth - the widow Ruth is brought to Boaz by higher governance, he simply cannot escape responsibility; the narrative is not concerned with the expectations of one character, but with a certain order in which the influential Boaz is to be available for this very occasion. When Ruth has successfully returned from Boaz's field, Naomi (who does not know

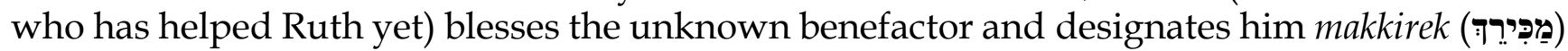
- "the one who has taken care of you". ${ }^{13}$

Naomi's expectations culminate on discovering that the benefactor is Boaz. According to Naomi, the Lord's kindness for the living and the dead (!) is apparently to come through Boaz - thus Boaz is to become a means of God's mercy (Ruth 2:20). By this the character Naomi expressly formulates the theological perspective of the book - God is merciful to humans and their descendants, especially by means of the mercifulness of other humans, in this case of the rich and successful Boaz.

The means of help is to be their kinship and Boaz's status of "redeemer" (Ruth 2:20). The word

11 The consonant text assumes the reading meyudda' ("Known, familiar"), the vowel text corrects (so-called Qere) to moda' (עִָin, "relative"); kinship is implied by the further narrative, where he is identified as "redeemer". At Ruth 2:1 (and then again (!) at 2:3) he is presented as belonging to the clan of Elimelech.

12 "When the word is used elsewhere in the Hebrew Bible (e.g., Gen 24:12; 27:20), it is God who is said to cause something to happen. But here the narrator carefully avoids any specific reference to God's agency"; Kathleen A. Robertson FARMER, The Book of Ruth: Introduction, Commentary, and Reflections, in: The New Interpreter's Bible, ed. Leander E. KECK, Nashville, Tennessee: Abingdon Press, vol. 2, 1998, pp. 915f. 13 Thus according to the Revised Standard Version: "The man who took notice of you..." (Ruth 2:19); The Holy Bible Containing the Old and the New Testaments: Revised Standard Version, New York: Thomas Nelson, 1952, ad loc. 
go'el,"14 i.e., "redeemer", designates a relative who is to act as benefactor or patron of an underprivileged person or family, especially to: redeem a piece of land which the family has been obliged to sell in an economically pressing situation (Lev 25:25-30); redeem a relative who has been obliged to sell himself into "slavery" for economic reasons (Lev 25:47-55); take

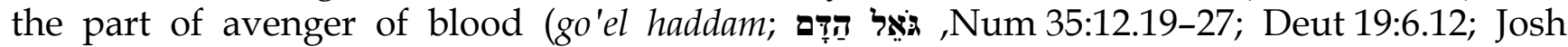
20:2-3.5.9); receive compensation (after the injured person has died?, cf. Num 5:8); apparently also to act as advocate or patron in the context of a trial (Job 19:25; Ps 119:154; Prov 23:11; Jer 50:34; Lam 3:58) - inל $\left(G^{\prime} L\right)$ is apparently metaphorically applied to the Lord. One of the "legal problems" of the book of Ruth is that it uses this term in connection with a request to marry a widowed relative - i.e., besides redeeming property there is also marriage with a relative and the question of inheritance involved. ${ }^{15}$ It is uncertain whether this is a logical (though perhaps at first surprisingly creative) application of the custom on the part of Boaz, or whether it is a case of misunderstanding the function of redeemer on the part of Ruth, as she learns about it from Naomi. In the latter case Boaz may have perceived the offer of marriage from Ruth as the proverbial taking a whole yard instead of the offered inch. ${ }^{16}$

\section{Boaz as the object of feminine seduction}

The narrative does not employ only the passive expectations of the female characters. Naomi's plan ${ }^{17}$ to "seek rest" for Ruth "that it may be well with her" becomes a part of the plot. Naomi's plan evidently assumes that Ruth will seduce Boaz, which she will then be able to use for the benefit of both women. ${ }^{18}$ The scene at Boaz's threshing floor is open to various interpretations. In any case Ruth starts acting according to Naomi's plan, which gives rise to many questions on the part of the reader: Will this be another case of a "Moabite seduction" in the style of Lot's daughters (Gen 19:30-38)? Is Boaz in danger of committing idolatry due to fornication with a Moabite (Num 25:1ff) ${ }^{19}$ Will Ruth try to use or abuse Boaz's weakness, inebriation and elevation (Ruth 3:3.7)? It is unclear whether Ruth failed to understand Naomi's plan of seducing Boaz, or whether she merely feigned consent and went to Boaz to follow her own purpose..$^{20}$ The situation goes fairly far, to the "uncovering of feet" (Ruth 3:7), which most commentators take to mean the nakedness of one of the protagonists, most commonly Boaz. ${ }^{21}$

14 Root $G^{\prime} L$ (גאר). On its use cf. Helmer RINGGREN, גאל (g'1), in: Theologisches Wörterbuch zum Alten Testament, ed. G. Johannes BOTTERWECK - Helmer RINGGREN, Stuttgart: Kohlhammer, vol. 1, 1973.

15 The legal aspect of the book Ruth is concisely summarized by Robert L. HUBBARD, JR., The Book of Ruth, Grand Rapids, Michigan: Eerdmans, 1988 , pp. 48-63. Hubbard identifies the three fundamental legal issues underlying the plot of the book of Ruth: inheritance, redemption, and remarriage of a childless widow. Hubbard believes that in the case of Ruth her request to marry Boaz is a justified application in the area of redemption law $\left(G^{\prime} L\right)$.

16 Adele Berlin develops Sasson's interpretation according to which Naomi sends Ruth to Boaz as "to a relative" in order for Ruth to seduce him, not to address him as a "redeemer". According to Berlin Ruth failed to understand this plan of Naomi's and appeals to him precisely as to a redeemer - Boaz is embarrassed by this since there is another redeemer, but graciously covers Ruth's faux pas by his eloquence; Adele BERLIN, Poetics and Biblical Interpretation, Winona Lake, Indiana: Eisenbrauns, 1994, p. 90.

17 It is in fact a narrative of several "secret plans": Naomi in relation to Ruth and Boaz. Ruth partially diverges from Naomi's plan - either due to ignorance (see note above), or intentionally. Boaz elaborates his plan aimed at acquiring the right to redeem Ruth with respect to the other redeemer. The way the narrator works with the characters' plans is important also for the theological and ethical outcome of the narrative. The characters' motivations are not always fully clear; though they mostly contribute to positive development, behind which the reader can sense Divine agency and in fact even Divine plan, cf. Moshe REISS, Ruth and Naomi: Foremothers of David, Jewish Bible Quarterly, vol. 35, 3/2007, p. 193.

18 Thus paradoxically Boaz becomes the object of seduction - rather than Ruth, whose sexual harassment Boaz fears (Ruth 2:8f). Naomi's plan apparently consists in an attempt to simply seduce Boaz by means of Ruth and manipulate him into a situation when he would have to marry her, or at least be obliged to compensate her financially.

19 This motif is developed by Danna Nolan FEWELL - David Miller GUNN, Compromising Redemption, pp. 78f.

20 Ruth does not wait (as Naomi had advised her) for Boaz to start speaking or acting and apart from stating her name she also makes a specific request (Ruth 3:9; cf. 3:4).

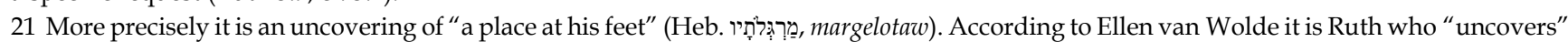
herself - i.e., undresses at Boaz's feet, thereby inciting him to intercourse; Ellen VAN WOLDE, Intertextuality: Ruth in Dialogue with Tamar, in: Feminist Companion to Reading the Bible: Approaches, Methods and Strategies, ed. Athalyah BRENNER - Carole FONTAINE, Sheffield: Sheffield Academic Press, 1997, pp. 444f. The problem of the interpretation is that in the text there is no object accompanying the verb "uncover" (Hebrew GLH in Piel), in the proposed meaning we would much rather expect the verb in Nifal. 
But at this moment two twists occur in the plot, which do not conform to the plan of seducing Boaz, as the reader has gathered it from Naomi's instructions. First Ruth conducts an unusual rhetoric manoeuvre, when she applies Boaz's original words of the Lord's protective wing (Ruth 2:12) to himself (3:9). Ruth requests that Boaz himself extend "his wing" 22 over her and exhorts him to act as go'el - redeemer. ${ }^{23}$ On the other hand, from the point of view of Naomi's plan Boaz acts absurdly correctly. He is aware of Ruth as a woman with a certain sex-appeal (3:10). However, he does not try to make use of her availability at the present moment and expresses his intention to proceed with respect to the man who has a greater claim to the role of the redeemer than he does. ${ }^{24}$ Boaz also wards off another danger and avoids even a suspicion of intimate relations with Ruth. He does that in an adroit manner, by means of a gift of "six measures of barley" (3:15), whereby he also manifests his generosity and goodwill towards Ruth. She brings grain from the thrashing floor, which outwardly provides at least a formal justification of her presence there ${ }^{25}$ and enables Boaz to act freely and carry out his own plan.

\section{Aspirations and anxieties of a rich and influential man}

In the character of Boaz the narrator links the topic of the private and public life of a man of influential standing in an interesting way. ${ }^{26}$ His interest in Ruth manifests itself from the beginning at several levels. Boaz is aware of the kinship of Ruth and Naomi and thus perhaps of his own kinship with Ruth. Outwardly he behaves to Ruth in a friendly fashion, generously, even mercifully, but his interest is complicated. Boaz raises the question of Ruth's safety from harassment on the part of young men, which suggests that he perceives Ruth with respect to her female sexuality. ${ }^{27}$ According to some commentators his own interest manifests in this, it is a case of a "Freudian slip" 28 , an outpour of his own secret desires. If that is the case, then the narrative in this respect at least partially deals with Boaz's need, with his unfulfilled lonely life so far (Gen 2:18). ${ }^{29}$

Commentators mostly note the temporal specification in Ruth 2:23 - Ruth goes to Boaz's field as long as the harvest continues, but we do not learn of any further contact with him, his interest in Ruth does not manifest itself further. There are several possible explanations of Boaz's silence, mostly connected with his affluence and standing in the community, which limit him in fulfilling his obvious desire for a relationship with Ruth.

First of all one can infer that the Moabite origin of Ruth may be perceived as an obstacle to direct action on the part of Boaz. The narrator (either directly or by means of direct speech of the characters) links the name of Ruth with the attribute "Moabite", which may function as an expression of the ambiguous attitude of the community to Ruth and of a certain caution with

\footnotetext{
22 ČEP at Ruth 3:9, just as at 3:7, inserts "cloak", i.e., "wing of cloak".

23 As noted above, the narrator may be construing Ruth as a foreigner who is not quite clear about the precise role of a "redeemer", which may result in comical situations - Naomi has identified Boaz as "redeemer", but she knows that the role does not necessarily ground an obligation to beget a son for the deceased, therefore she sends Ruth to seduce Boaz. But instead of employing feminine tricks Ruth appeals to Boaz as redeemer with a hope of something like a levirate marriage.

24 It is interesting that there is no mention of this man earlier in the narrative. Thus the reader must ask if Naomi had known of the "nearer redeemer" and had intentionally failed to inform Ruth of his existence so as not to complicate the seduction of Boaz by ethical and legal considerations.

25 The narrator thereby symbolically prefigures Boaz's "gift of seed" on marrying Ruth.

26 Yitzhak Berger (besides the frequently cited parallel Ruth / / Gen 38) seeks another parallel between David and Boaz - two influential men, one of whom fails in a critical situation (with Bathsheba), while the other one (with Ruth) comes out with honour; cf. Yitzhak BERGER, Ruth and the David-Bathsheba Story: Allusions and Contrasts, Journal for the Study of the Old Testament, vol. 33, 4/2009.

27 He also speaks of Ruth as of a "girl", (na'arah, נְּרָה ) - despite several years of her previous marriage. The term may also connote "marriageable young woman" (Robert L. HUBBARD, JR., The Book of Ruth, p. 146), in this sense one can also interpret Boaz's question "Whose girl is it?" (Ruth 2:5). On the other hand the title may signal the age difference between the characters - cf. ibid., p. 154 .

28 Danna Nolan FEWELL - David Miller GUNN, Compromising Redemption, p. 85.

29 There is no mention of Boaz's family except for his kinship with the deceased Elimelech.
} 
respect to her, which even Boaz must take seriously - he cannot simply compromise himself by a relationship with a Moabite.

Boaz is equivocally depicted as a careful man, perhaps even too careful. His eloquence contrasts with his reluctance as far as direct action is concerned - at least in harvest time. Finally Ruth must even leave the threshing floor incognito, with respect to the existence of a "nearer redeemer" and the plan prepared by Boaz, but perhaps also simply with respect to Boaz's reputation.

Boaz is forced to proceed wisely, correctly and according to customs - he deals with "the Ruth situation" formally correctly, at the town gate in the presence of ten elders; at the same time Boaz's action is marked by cleverness and cunning, since he succeeds first in covering his own interest in Ruth and gaining her thereby, then in cleverly presenting his marriage to Ruth as a noble self-sacrifice (which the nearer redeemer would not have been willing to undergo), which may increase his prestige and respect in the community. ${ }^{30}$

\section{From Boaz to today"s "men of affluence"}

The narrative of the book of Ruth works with Boaz as with a fairly complicated character. At the forefront of the narrative Boaz is depicted as a type of successful rich man, who elicits the deserved respect of his community. When Boaz meets Ruth, he is confronted with poverty, insecurity, and risk of social exclusion. The narrator underlines the confrontation by the explicit as well as hinted expectations of Naomi and Ruth with respect to Boaz. On the theological level these expectations are supported by indirect reference to Divine providence behind all apparently chance events, as well as behind rather cunningly elaborated human plans.

In newer contributions to interpreting the book Ruth, which we have cited more or less extensively in this paper, the character of Boaz, particularly his positive interpretation, is frequently deconstructed. Fewell and Gunn look for sexual undercurrent in Boaz's interest in Ruth, ${ }^{31}$ in Boaz's prudent dealing with Ruth and in his clever plot with respect to the nearer redeemer they see an effort to "redeem" his own good reputation, ${ }^{32}$ they perceive him as a character guarding patriarchal values (rather than the economic interest of relatives in need), where finally Boaz's name is glorified, not the name of his deceased relative, which begetting a son with the widow Ruth should originally have served. ${ }^{33}$

Nehama Aschkenasy suggests interpreting the book Ruth with reference to M. M. Bakhtin's concepts of the dialogic and the carnivalesque. ${ }^{34}$ In the book of Ruth she finds the main "Bakhtinian" concepts, such as "heteroglossia" (the presence of various, even contradictory voices, views, speech styles), as well as "carnivalesque features" (comicality, "spirit of revelry, mockery", alcoholic intoxication etc.). ${ }^{35}$ Armed by this approach Aschkenasy interprets the character of Boaz as a representation of the establishment ("pillar of community"), which during the carnivalesque reversal of roles (i.e., at the time of harvest in the book of Ruth)

\footnotetext{
30 Thus again Danna Nolan FEWELL - David Miller GUNN, Compromising Redemption, pp. 91f.

31 While appreciating his willingness not to rush things. Ibid., pp. $84 \mathrm{ff}$.

32 Intermingled with his willingness to act for the benefit of Ruth. Ibid., pp. 86f, 88f.

33 Ibid., pp. 92 f.

34 Nehama ASCHKENASY, Reading Ruth through a Bakhtinian Lens: The Carnivalesque in a Biblical Tale, Journal of Biblical Literature, vol. 126, 3/2007.

35 There are similar (and perhaps more meaningful) interpretations along these lines of the book of Esther, cf. e.g. Adele BERLIN, Esther: The Traditional Hebrew Text with the New JPS Translation, Philadelphia, Pennsylvania: Jewish Publication Society, 2001.
} 
temporarily loses his respectable status and gets involved in unrestrained folk merriment. In relationship to Ruth Boaz appears as a comic type of a slightly infatuated elderly man, which on this interpretation of Ruth contributes to popular critical reflection of the traditional social order Boaz represents. This motif culminates at the moment when in the course of the night scene at the threshing floor Ruth makes an offer of marriage to Boaz, whereby the carnivalesque reversal of traditional roles is completed.

The above examples of fairly recent interpretations of the book Ruth and the character of Boaz are beneficial especially in that they break the possibly schematic perception of biblical characters as one-dimensional positive heroes. However, one must take care that this type of reading does not (though in a different way) flatten the biblical characters into simplified caricatures. In our interpretation we have therefore rather attempted to represent Boaz as a man living in a tension between his public responsibility deriving from his standing, the expectations of his surroundings, and his own personal desires and aims. In the narrative reflection of the book Ruth $^{36}$ Boaz fights the fight of a rich man, affluent in his community. He is once prudent, once too hesitant, once active, then again cunning and assertive. He follows his own desires, but at the same time he lives up to his reputation of a capable man and contributes not only to successfully solving the situation of relatives in an oppressive situation. By all that he becomes part of a broader Divine purpose.

Theological reading of $R u t h$, including the character of Boaz, must stem from the delicate way this narrative talks of God. Even though deconstructive reading of the individual characters and their motives is possible, it is hard not to perceive the positive development in the plot: from death to life, ${ }^{37}$ from exclusion to incorporation, from famine to prosperity, from insignificance to finding one's significance in the wider story of the community. ${ }^{38}$

A challenge of this interpretation of the book of Ruth and especially the character of Boaz remains to what extent it can be inspiring for our contemporary attitude to "men and women of affluence". The narrative of Ruth is interesting in that it can imagine a positive part for an important and rich person in God's plans and relationships to other people, without being uncritically naive and too far removed from our own experience.

\section{The World According to Boaz: Wealth, Power, and Justice in the Book of Ruth}

Abstract The paper offers a literary-theological study of the character of Boaz in the book of Ruth. It analyses the narrative characteristic of Boaz as a "successful and influential man" and traces the way Boaz's position functions in developing the economic, social and theological motifs in the book of Ruth. In the conclusion the author focuses on the tension between the traditional interpretation of the character of Boaz as an unambiguously positive character and newer approaches largely deconstructing this traditional picture.

Key words the book of Ruth, (narrative interpretation), Boaz (character), wealth, ethics

\footnotetext{
36 I am aware of the debt this paper owes the other characters of the Ruth scroll. The narrative analysis of the characters of Naomi and Ruth would no doubt be worth detailed elaboration, at present it is necessary at least to refer to the cited literature.

37 Ruth's pregnancy with Boaz is the only act the narrator expressly attributes to the LORD; Thomas W. MANN, Ruth 4, Interpretation, vol. 64, 2/2010, p. 179.

38 The dynamics of the theology of the book of Ruth is similarly perceived by Nathan Tiessen who applied Brueggemann's categories of core testimony and countertestimony to the book; Nathan TIESSEN, A Theology of Ruth: The Dialectic of Countertestimony and Core Testimony, Direction, vol. 39, 2/2010.
} 